\title{
University pay grumbles remain
}

The ways in which Canada's Royal Society might have a broadened role in the country's scientific affairs is becoming a matter of some controversy. From Ottawa, David Spurgeon reviews the main issues, which focus chiefly on the question of relations with the government.

THE contract for $\$ 75,000$ over a 12 month period which was signed not long ago between the Canadian federal government and the Academy of Sciences of the Royal Society of Canada will enable the academy to undertake a study to identify specific missions in the natural and human sciences that may be of value to the government, and to recommend policies and procedures for carrying them out. Thus, apart from allowing the academy to engage an executive director half-time-he is Donald Hurst, former head of the Atomic Energy Control Board of Canada, the country's regulatory agency in nuclear affairsthe contract may give it a broadened role in Canada's scientific affairs, the implications of which do not delight all its members.

A number of initiatives designed to make the Royal Society more influential in scientific affairs has been taken in recent years. Five years ago, a committee set up by the Society's old Section Three (now the Academy of Sciences) to study how this could be done became a committee of the Society as a whole within months. Now there are three component academies in the Society, the other two being those of the social sciences and humanities (one for the Anglophone section, the other for the French).

One of the reasons some have felt the need of a stronger role for the Royal Society in science was expressed by the geologist J. Tuzo Wilson when he was president in 1973. In an article in Science Forum he said that the Society believed that Canada needed "an active and independent academy, not so much to advise government, but to promulgate informed opinions and to lead open discussions of important issues that will aid governments in making their decisions".

Dr Wilson stressed that, unlike the various bodies the government had established for similar purposes, the Royal Society was not a political body. $\mathrm{He}$ suggested that its independence, together with its access to leading scientists in many fields, could provide the alternative in scientific advice that the country needed. It was his view that the whole direction of Canadian science was in the hands of civil servants and members of councils who are appointed by ministers, and he claimed that the whole direction of science had been "politicised".

Not all Society members have agreed on the role the body should take, however. Although some, like Wilson, thought a detached role (in which the Society would make studies in specific areas) was best, others thought it should be closer to the government and play a more official advisory role.

Part of the Society's expanded role may be in international scientific affairs. In other countries, contacts with international scientific unions are usually made through non-governmental bodies, but in Canada the National Research Council has usually provided the point of contact. Some think this anomalous. For the social sciences, the humanities and engineering, Canada has non-governmental organisations that can act as adhering bodies to the international unions: the Social Science Research Council, the Humanities Research Council, and the Canadian Council of Professional Engineers. But there are no corresponding non-governmental bodies for international contact in the medical and natural sciences.

Some members of the Royal Society believe this is a role the Society should play, as academies do in other countries. But the problem of how this could be done remains because of the large number of professional organisations in different disciplines in Canada and the number of constituent bodies of the international scientific unions. One suggestion is that the Society should play the role of clearing house for the appropriate national professional organisations.

A certain amount of scepticism usually accompanies changes which the Royal Society of Canada makes, mainly because many scientists have become accustomed to thinking of the organisation as a self-congratulatory old boys' club. In spite of this, the 'club' counts among its members many of the country's most distinguished scientists (and lately even a few engineers), and it has been stirring itself in recent years to play a more important public role-for example by organising seminars on such topics as the energy problem. The outcome of this latest move will thus be watched with interest.
Last year British university teachers were involved in 'industrial action' before finally resolving their dispute with the government over salary increases. The government has since introduced its pay policy. This month many academics will receive for the first time the cost of living element of their 1975 salaries settlement. David Walker reports on the discontent that still prevails.

THE Association of University Teachers (AUT), the university authorities and the British goverment have agreed that the pay code maximum of $£ 6$ a week should be added to all academic salaries under $£ 8,500$ a year, and the whole package backdated to October. The final figures for the delayed settlement-the basic element was determined by an arbitration body as long ago as May last year-show that junior lecturers have probably benefited most and now start their teaching careers on nearly $£ 3,200$ a year. Some staff, who will no doubt bear in mind $\mathrm{Mr}$ Healey's recent warning about "confetti money", have increased their annual salaries by $£ 1,000$ in the space of 12 months. And one professor of politics told the world on television before Christmas that he was "aggressively satisfied" with his standard of living.

Under the settlement the starting point for all university academic staff, the foot of the lecturer grade, is $£ 3,174$ a year rising through 16 incremental points to $£ 6,446$. The scale for senior lecturers and readers will now run from $£ 6,234$ to $£ 7,742$, and the professorial minimum salary will be just below $£ 7,900$. Professors outside the clinical subjects will be on an average of over $£ 9,200$, although few of them got the $£ 6$ a week element or at least got only enough of it to take them to the $£ 8,500$ salaries ceiling. The settlement will run for the duration of the Labour government's incomes policy and $\mathrm{Mr}$ Laurie Sapper, the general secretary of the AUT, claims they have extracted from the government a firm promise to revise the scales of payment as soon as economic circumstances permit.

In spite of that, there is a lingering mood of dissatisfaction in those senior common rooms where salaries get discussed-and it is a sign of the times that money now gets talked about in public. Those university teachers who take an active part in their trade union (and a key test of their 'militancy' will come in March when they will vote on whether the AUT should affiliate to 